\title{
Heavy Metals Uptake by Select Plant Species in the Landfill Area of Štěpánovice, Czech Republic
}

\author{
Magdalena Vaverková*, Dana Adamcová \\ Department of Applied and Landscape Ecology, Faculty of Agronomy, Mendel University in Brno, \\ Zemědělská 1, 61300 Brno, Czech Republic \\ Received: 11 March 2014 \\ Accepted: 9 May 2014
}

\begin{abstract}
Vegetation can be used as bioindicators of site pollution by identifying the mobilization of heavy metals. This study was conducted to screen plants growing in a landfill site to determine their potential for metal accumulation. Plants selected were the Tanacetum vulgare and Lycopersicon esculentum. Based on results, it may be concluded that Tanacetum vulgare can tolerate and sequester $\mathrm{Cd}$ from the soil. None of the plants were identified as metal hyper accumulators. However, Tanacetum vulgare was most effective in taking up metals and showed a higher enrichment coefficient of heavy metals, indicating its higher accumulation ability.
\end{abstract}

Keywords: landfill, waste, heavy metals, Tanacetum vulgare, Lycopersicon esculentum

\section{Introduction}

Human activity has continuously increased the level of heavy metals circulating in the environment. Heavy metal pollution of the biosphere has accelerated rapidly since the onset of the industrial revolution, and heavy metal toxicity poses major environmental problems [1, 2]. Heavy metals belong to types of toxic substances that have adverse effects on health. The most common ones are $\mathrm{Cd}, \mathrm{Cr}, \mathrm{Cu}$, $\mathrm{Hg}, \mathrm{Pb}$, and $\mathrm{Zn}$, having their atomic number greater than 20 and with metallic properties. These metals cannot be easily degraded, and cleanup usually requires their removal $[3,4]$.

Waste landfills are currently the most widely used method to dispose of municipal waste, mainly in highly populated cities. Landfills can be a source of a large number of toxic elements and compounds, i.e. heavy metals diffuse through air fallout or leachate release. Some research has shown that landfills spread a large number of compounds that, since the industrial revolution, are

\footnotetext{
*e-mail: magda.vaverkova@uake.cz
}

increasingly accumulated in soil and in litter and that in some situations may be available for species even a considerable distance from the source [5]. Toxic and heavy metals may be leached, absorbed by vegetation, or retained by the soil, and their toxicity depends on factors such as concentration, speciation (the form in which they are present in the soil), and bioavailability (the ease with which they pass into the soil solution and thereby into the tropic chain) [6].

The plants, which are often identified as bioaccumulators, have the ability to take up soil contaminants and deposit them in their roots, as well as in their aboveground organs. According to Kowalska [7] it is necessary to point out that bioaccumulating plant species are normally characterized by high concentration factors, i.e. concentrations of the toxic substances are higher in their tissues than in the soil. Bioaccumulation factors of some plants can even reach $1000 \times$. There are plant species capable of intensive uptake of soil contaminants and, at the same time, are characterized by a significant production of biomass [7].

In this study the concentrations and the enrichment coefficient (EC) of $\mathrm{Cd}, \mathrm{Cr}, \mathrm{Cu}, \mathrm{Ni}, \mathrm{Pb}$, and $\mathrm{Zn}$ of plant 
Table 1. Sample designation

\begin{tabular}{|l|c|}
\hline \multicolumn{1}{|c|}{ Sample - sampling area } & Designation \\
\hline $\begin{array}{l}\text { Lycopersicon esculentum - landfill sampling area } \\
\text { No. 1 }\end{array}$ & Sample A \\
\hline $\begin{array}{l}\text { Lycopersicon esculentum - landfill sampling area } \\
\text { No. 2 }\end{array}$ & Sample B \\
\hline Tanacetum vulgare - landfill sampling area No. 1 & Sample C \\
\hline Tanacetum vulgare - landfill sampling area No. 2 & Sample D \\
\hline
\end{tabular}

species Lycopersicon esculentum and Tanacetum vulgare in Štěpánovice municipal solid waste (MSW) landfill was investigated with the objective to:

(1) Get better knowledge of the accumulating capacity of plant species for $\mathrm{Cd}, \mathrm{Cr}, \mathrm{Cu}, \mathrm{Ni}, \mathrm{Pb}$, and $\mathrm{Zn}$ in such environment conditions

(2) Investigate the enrichment coefficient of the plant/soil system

(3) Choose a hyper accumulator that would be used as potential plant species for cleaning heavy metals in the future.

It was hypothesized that differences in the concentrations and the enrichment coefficients of $\mathrm{Cd}, \mathrm{Cr}, \mathrm{Cu}, \mathrm{Ni}, \mathrm{Pb}$, and $\mathrm{Zn}$ of plant species in Štěpánovice MSW landfill exist.

\section{Experimental Procedures}

The following two species were the object of the investigation: Tanacetum vulgare and Lycopersicon esculentum. They have been used as indicator species in the phytomonitoring of pollution in the Štěpánovice MSW landfill. The investigation was carried out in 2013, and each of the two species was studied. Two experimental plots were set (Fig. 1) for the purpose of monitoring. The selection of experimental plots was made in compliance with wider distribution of those plant species. The content of the $\mathrm{Cd}, \mathrm{Cr}, \mathrm{Cu}$, $\mathrm{Ni}, \mathrm{Pb}$, and $\mathrm{Zn}\left(\mathrm{mg} \cdot \mathrm{kg}^{-1}\right.$ dry matter (DM)) was determined in the plant species.

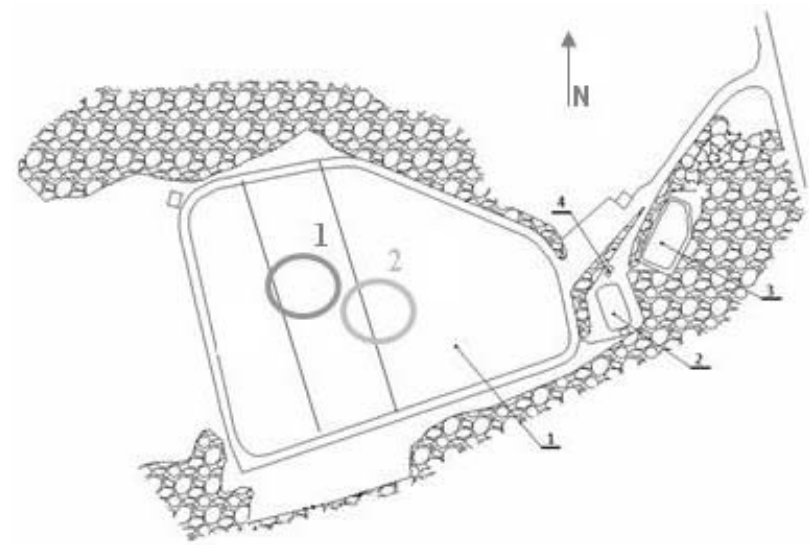

Fig. 1. Sampling area.

1 - landfill, 2 - drained water tank, 3 - rainwater reservoir, 4 entrance gate

\section{Site Description}

The investigated landfill (site description - location and characterization) was described in detail in other articles [810]. The site is reported to have experienced waste disposal activities from 1996 until 2014 at varying rates. Particular details of waste composition, waste quantity stored in the landfill from 2004 to 2011, and landfill gas management are not presented in this article.

\section{Tanacetum vulgare Collection and Analysis}

Two samples of whole Tanacetum vulgare were collected from the landfill body (Fig. 1). Height of the plants ranged from 30 to $60 \mathrm{~cm}$ at the time of harvest. Plant materials were harvested at the end of May 2013. Tanacetum vulgare were uprooted, labeled, and taken to a laboratory for analysis. Fresh plant material was air dried between the sheets of porous paper for about a month. Dried samples were ground to fine powder using pestle and mortar and were then chemically analyzed for the content of $\mathrm{Cd}, \mathrm{Cr}$, $\mathrm{Cu}, \mathrm{Ni}, \mathrm{Pb}$, and $\mathrm{Zn}$. Concentration of heavy metals was analyzed according to ČSN EN ISO 11885. For the determination of the contents of trace elements, the samples were mineralized by microwave digestion with $\mathrm{HNO}_{3}$ and $\mathrm{H}_{2} \mathrm{O}_{2}$.

\section{Lycopersicon esculentum Collection and Analysis}

Two whole samples of Lycopersicon esculentum were taken from the same place as Tanacetum vulgare (Fig. 1). Height of the plants ranged from 30 to $45 \mathrm{~cm}$ at the time of harvest. Plant materials were harvested at the end of May 2013. Samples were placed into two separate carrying boxes made of perforated paper. The boxes were labelled for easy identification and brought to the laboratory where they were photographed for documentation and prepared for further research. The examined samples of Lycopersicon esculentum were brought to the laboratory for analyses. The materials were analyzed for the content of $\mathrm{Cd}, \mathrm{Cr}, \mathrm{Cu}, \mathrm{Ni}, \mathrm{Pb}$, and $\mathrm{Zn}$. Concentration of heavy metals was analyzed according to ČSN EN ISO 11885. For determining the contents of heavy metals the samples were mineralized by microwave digestion with $\mathrm{HNO}_{3}$ and $\mathrm{H}_{2} \mathrm{O}_{2}$.

\section{Soil Sampling and Analysis}

The soils were sampled at $0-15 \mathrm{~cm}$ depths under the tansy Tanacetum vulgare and Lycopersicon esculentum roots and transferred into labeled polyethylene bags for storage and laboratory analyses (Fig. 1). Soil samples were dried at $105^{\circ} \mathrm{C}$ until constant weight, ground to fine powder, and homogenized. The samples were collected from four different places in both sampling areas. The materials were analyzed for contents of $\mathrm{Cd}, \mathrm{Cr}, \mathrm{Cu}, \mathrm{Ni}, \mathrm{Pb}$, and $\mathrm{Zn}$. Concentration of heavy metals was analyzed according to ČSN EN ISO 11885. 


\section{Enrichment Coefficient for Plant/Soil System}

Enrichment coefficient (EC) was calculated to assess the accumulations of metals from soils to plants (1), and it is described as the following formula $[1,11,12]$ :

$$
E C^{\prime}=\frac{[M]_{\text {plant }}}{[M]_{\text {soil }}}
$$

...where $E C$ is the enrichment coefficient for plant/soil system; $[M]_{\text {plant }}$ is the concentration of a metal in the tissue of plant (root or leaf), $\mathrm{mg} \cdot \mathrm{kg}^{-1}$, in dry matter; and $[M]_{\text {soil }}$ is the total concentration of a metal in soils where this plant used to grow, $\mathrm{mg} \cdot \mathrm{kg}^{-1}$, in dry matter.

\section{Results and Discussion}

The soil and plant samples collected from four sites were analyzed for their metal contents. It appears that metal concentration in different samples varies to a great extent from sample to sample.

Table 1 describes the characteristics of samples (plant species), location of sampling area, and sample designation.

Fig. 1 illustrates the landfill and its immediate surroundings and the marked areas of sampling. In sampling area No. 1 sample A - Lycopersicon esculentum and sample $\mathrm{C}$ - Tanacetum vulgare were collected. In sampling area No. 2 sample B - Lycopersicon esculentum and sample D - Tanacetum vulgare were collected.

The results of enrichment coefficient for plant/soil system are shown in Figs. 2-6. Malayeri et al. [13] grouped plant species according to their heavy metal uptake capacities and sensitivity to metal pollution:

$\begin{array}{ll}\text { High accumulator plants } & \text { EC }>1 \\ \text { Moderate accumulator plants } & \text { EC }<1.0 \\ \text { Low accumulator plants } & \text { EC }<0.1 \\ \text { Non-accumulator plants } & \text { EC }<0.01\end{array}$

Fig. 2 shows graphical evaluation of the results for values of the $\mathrm{EC} \mathrm{mg} \cdot \mathrm{kg}^{-1} \mathrm{DM}$ for $\mathrm{Cd}, \mathrm{Cr}, \mathrm{Cu}, \mathrm{Ni}, \mathrm{Pb}$, and $\mathrm{Zn}$ in sample A (sampling area No. 1).

In sample $\mathrm{A}$ the values of the $\mathrm{EC}$ for $\mathrm{Cr}, \mathrm{Cu}, \mathrm{Ni}, \mathrm{Pb}$, and $\mathrm{Zn}$ were lower than $0.01 \mathrm{mg} \cdot \mathrm{kg}^{-1} \mathrm{DM}$; no accumulation occurred. Only Cd reached EC figure of $0.0546 \mathrm{mg} \cdot \mathrm{kg}^{-1}$

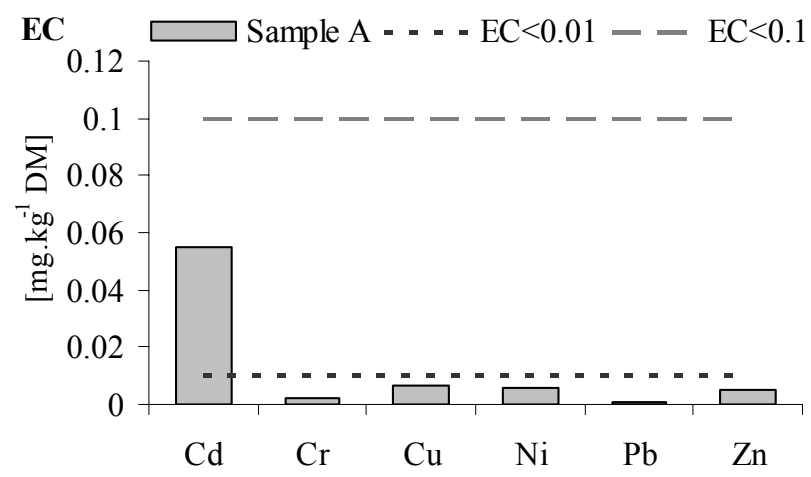

Fig. 2. EC for sample A.

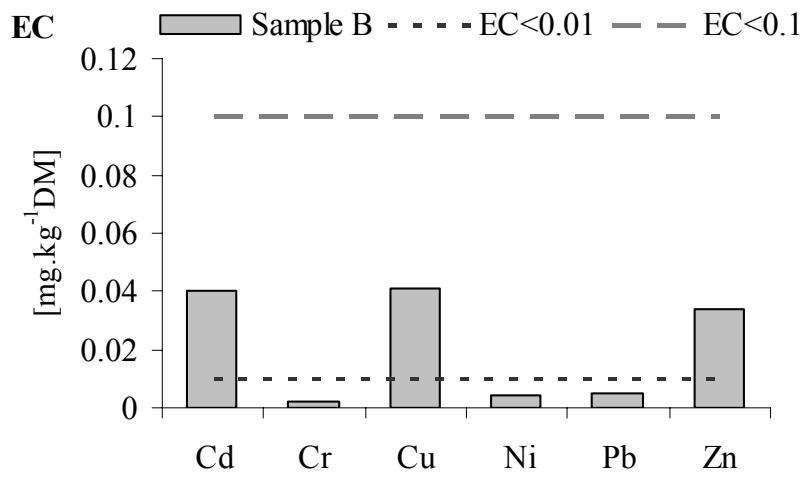

Fig. 3. EC for sample B.

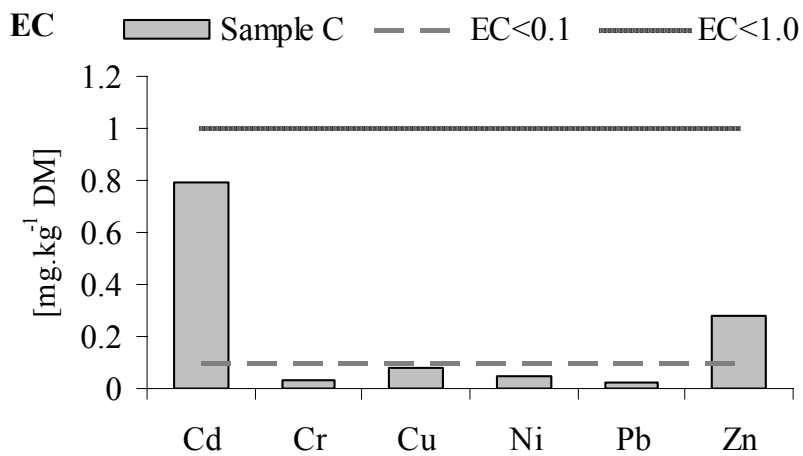

Fig. 4. EC for sample C.

DM, i.e. EC $<0.1$, low degree of accumulation. Fig. 3 illustrates graphical evaluation of the results for the $\mathrm{EC}$ values $\left(\mathrm{mg} \cdot \mathrm{kg}^{-1} \mathrm{DM}\right.$ ) for $\mathrm{Cd}, \mathrm{Cr}, \mathrm{Cu}, \mathrm{Ni}, \mathrm{Pb}$, and $\mathrm{Zn}$ in sample $\mathrm{B}$ (sampling area No. 2).

With regard to sample $\mathrm{B}$ the values of the $\mathrm{EC}$ for $\mathrm{Cr}, \mathrm{Ni}$, and $\mathrm{Pb}$ reached values lower than $0.01 \mathrm{mg} \cdot \mathrm{kg}^{-1} \mathrm{DM}$, thus accumulation did not occur. For $\mathrm{Cd}, \mathrm{Cu}$, and $\mathrm{Zn}$ the EC values were $\mathrm{EC}<0.1$, therefore a slight degree of accumulation was presented.

Fig. 4 shows graphical evaluation of the results for EC values $\left(\mathrm{mg} \cdot \mathrm{kg}^{-1} \mathrm{DM}\right)$ for $\mathrm{Cd}, \mathrm{Cr}, \mathrm{Cu}, \mathrm{Ni}, \mathrm{Pb}$, and $\mathrm{Zn}$ in sample $\mathrm{C}$ (sampling area No. 1).

In sample $\mathrm{C}$ the $\mathrm{EC}$ values for $\mathrm{Cr}, \mathrm{Cu}, \mathrm{Ni}$, and $\mathrm{Pb}$ reached values lower than $0.1 \mathrm{mg} \cdot \mathrm{kg}^{-1} \mathrm{DM}$, thus a slight degree of accumulation occurred. With regard to $\mathrm{Cd}(\mathrm{EC}=$ $\left.0.7923 \mathrm{mg} \cdot \mathrm{kg}^{-1} \mathrm{DM}\right)$ and $\mathrm{Zn}\left(\mathrm{EC}=0.2793 \mathrm{mg} \cdot \mathrm{kg}^{-1} \mathrm{DM}\right)$, the $\mathrm{EC}$ value was $\mathrm{EC}<1.0 \mathrm{mg} \cdot \mathrm{kg}^{-1} \mathrm{DM}$, i.e. a medium degree of accumulation.

Fig. 5 illustrates graphical evaluation of the results for the EC values (mg. $\mathrm{kg}^{-1} \mathrm{DM}$ ) for $\mathrm{Cd}, \mathrm{Cr}, \mathrm{Cu}, \mathrm{Ni}, \mathrm{Pb}$, and $\mathrm{Zn}$ in sample D (sampling area No. 2). As the graph indicates, the EC values in sample $\mathrm{D}$ for most of the $\mathrm{Cr}, \mathrm{Cu}, \mathrm{Ni}, \mathrm{Pb}$, and $\mathrm{Zn}$ amounted to $\mathrm{EC}$ values $<1.0 \mathrm{mg} \cdot \mathrm{kg}^{-1} \mathrm{DM}$, i.e. medium degree of accumulation. For $\mathrm{Cd}$ the $\mathrm{EC}$ value reached $\mathrm{EC}=2.56 \mathrm{mg} \cdot \mathrm{kg}^{-1} \mathrm{DM}$, a value of $\mathrm{EC}>1.0 \mathrm{mg} \cdot \mathrm{kg}^{-1} \mathrm{DM}$, thus a high degree of accumulation.

Comparison of EC values for particular samples (sample A, B, C, and D) is illustrated in Fig. 6.

When comparing the EC values of particular samples, the highest degree of accumulation was recorded for sample D, the plant Tanacetum vulgare (sampling area No. 2). 


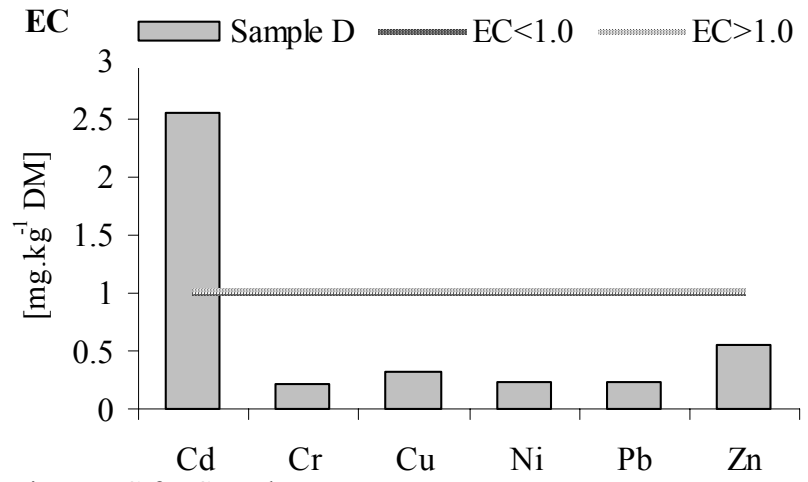

Fig. 5. EC for Sample D.

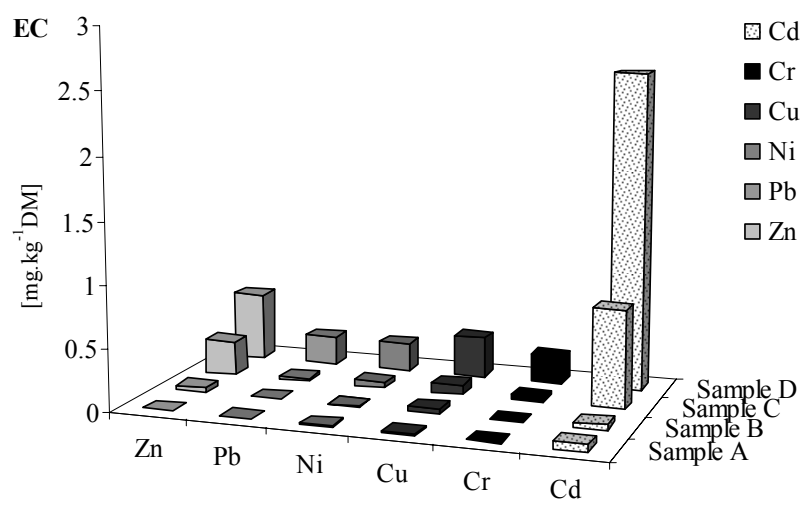

Fig. 6. Values of EC for particular samples.

The EC values for sample D - compared to samples A, B, and $\mathrm{C}$ - showed the highest figures of all examined heavy metals, but particularly for $\mathrm{Cd}$, the value was the highest of all the observed samples $\left(\mathrm{EC}=2.56 \mathrm{mg} \cdot \mathrm{kg}^{-1}\right)$; there was a high degree of accumulation.

\section{Discussion}

Environmental pollution with heavy metals poses a grave problem to the contemporary world. The ions of many heavy metals, such as $\mathrm{Cu}, \mathrm{Zn}, \mathrm{Mn}, \mathrm{Fe}$, and $\mathrm{Ni}$, are important microelements in the mineral nutrition of plants, but at high levels and jointly with other metals, such as $\mathrm{Cd}$ and $\mathrm{Pb}$, they could become extremely toxic [14].

Owing to their ability to effectively capture and accumulate chemical substances from the environment, the plants are widely used as passive biomonitors and for phytoremediation [14].

Phytoremediation is a method of environmental treatment that makes use of the ability of some plant species to accumulate certain elements, including heavy metals, in amounts exceeding the nutrition requirements of plants. Phytoextraction is one of the elements of phytoremediation: metals from the contaminated ground are taken up by plants and then transported from roots to shoots and removed with crops from a specified area of nature [15-17]. Considering the possibilities for phytoremediation of waste landfill sites, important are both the ability of species to accumulate high amounts of elements per biomass unit, as well as the possi- bility of high biomass production over a given time and area. This is not always possible for certain plant species, even if we provide optimal growth conditions and assume that high accumulation of cadmium or lead, for example, would not reduce this growth. Therefore, despite numerous studies on plant bioaccumulators [15-20], it is difficult to state definitively which species could be particularly useful in environmental phytoremediation [15].

Tanacetum vulgare was selected because it is a common and widespread plant with a high degree of adaptability and grows spontaneously in the Štěpánovice Landfill. Tanacetum vulgare's wide distribution indicates high ecological plasticity in different environmental conditions [21]. The wider distribution of Lycopersicon esculentum in the landfill body explains its use as an indicator and the start of a comparative investigation of the accumulation capacity of both pieces.

The samples were collected in two areas directly at the landfill body, in both sampling areas one specimen of Lycopersicon esculentum (soil and plant) and one of Tanacetum vulgare (soil and plant). The concentrations of $\mathrm{Cd}, \mathrm{Cr}, \mathrm{Cu}, \mathrm{Ni}, \mathrm{Pb}$, and $\mathrm{Zn}\left(\mathrm{mg} \cdot \mathrm{kg}^{-1} \mathrm{DM}\right)$ was determined in relation to all samples.

Based on the discovered concentrations of heavy metals in the samples, the EC ratios for particular collected specimens were calculated. The EC values for samples A and B were lower than $0.1 \mathrm{mg} \cdot \mathrm{kg}^{-1} \mathrm{DM}$ (a slight degree of accumulation), some heavy metals did not even reached values $\mathrm{EC}<0.01 \mathrm{mg} \cdot \mathrm{kg}^{-1} \mathrm{DM}$, which means there was no accumulation of these heavy metals. The EC values for sample $\mathrm{C}$ compared to the $\mathrm{EC}$ values for samples $\mathrm{A}$ and $\mathrm{B}$ reached higher figures, the degree of accumulation was low or moderate (in case of heavy metals $\mathrm{Cd}$ and $\mathrm{Zn}$ ). The highest values of EC were recorded for sample D in all the examined heavy metals, but especially in heavy metal $\mathrm{Cd}$, where the value of EC amounted to $2.56 \mathrm{mg} \cdot \mathrm{kg}^{-1} \mathrm{DM}$, which implies a high degree of accumulation.

In terms of the determination of the EC in case of Štěpánovice MSW landfill, better results were achieved using the plant Tanacetum vulgare rather than by means of the plant Lycopersicon esculentum. Since Tanacetum vulgare may be considered a good bioindicator, this plant was selected for further research that will focus on more detailed monitoring of Tanacetum vulgare in the nearest vicinity of the landfill and at its body.

\section{Conclusion}

There have been a number of studies investigating metal uptake in plants on contaminated landfill sites [15-20, $22,23]$, but little on their role as biomarkers to identify metal mobility for continuous monitoring purposes. Vegetation can be used as a biomonitor of site pollution, by identifying the mobilization of heavy metals and by providing an understanding of their bioavailability and for their phytoremediation possibilities.

For the phytoremediation of contaminated soils with heavy metals, plants representing high metal accumulation properties, high biomass production, and a high level of 
metal transportation from the root to the shoot appear to be useful for giving the highest possible heavy metal removal from the soil. Knowledge regarding the potential ability of plant mineral element uptake and their accumulation in the biomass is not sufficient, despite many studies on heavy metal content in different plants [15].

The present study was planned to assess the status of metal contamination in the MSW landfill area. Plants selected were the Tanacetum vulgare and Lycopersicon esculentum. The study area was predominantly contaminated with $\mathrm{Cd}$ and $\mathrm{Zn}$. The results indicated that select plant species differ greatly in their capacity of heavy metal accumulation.

This study was conducted to screen plants growing in contaminated areas of the landfill site to determine their potential for metal accumulation. Based on the results, it may be concluded that Tanacetum vulgare can tolerate and sequester $\mathrm{Cd}$ from the soil. None of the plants were identified as metal hyperaccumulators. However, Tanacetum vulgare was most effective in taking up metals and showed higher enrichment coefficient of heavy metals, indicating its higher accumulating ability. These plant species were considered suitable for growing in the MSW landfill, as they accumulate considerable quantities of heavy metals from the soil with their root system and can be used as a potential plant species for cleaning heavy metals. Enrichment coefficient (EC) indicates the phytoremediation potential of Tanacetum vulgare. Phytoremediation potential of these plant species especially needs to be investigated; further research will be undertaken.

\section{References}

1. YANQUN Z., YUAN L., SCHVARTZ CH., LANGLADE L., FAN L. Accumulation of $\mathrm{Pb}, \mathrm{Cd}, \mathrm{Cu}$ and $\mathrm{Zn}$ in plants and hyperaccumulator choice in Lanping lead-zinc mine area. China Environ Int. 30, (4), 567, 2004.

2. GISBERT G., ROS R., HARO A.D., WALKER D.J., BERNAL M.P., SERRANO R. NAVARRO-AVIÑÓ J. A plant genetically modified that accumulates $\mathrm{Pb}$ is especially promising for phytoremediation. Biochem. Bioph. Res. Co. 303, (2), 440, 2003.

3. ADESODUN J.K., ATAYESE M.O., AGBAJE T.A., OSADIAYE B.A., MAFE O.F., SORETIRE A.A. Phytoremediation Potentials of Sunflowers (Tithonia diversifolia and Helianthus annuus) for Metals in Soils Contaminated with Zinc and Lead Nitrates. Water Air Soil Poll. 207, (1-4), 195, 2010.

4. LASAT M. M. Phytoextraction of metals from contaminated soil: A review of plant/soil/metal interaction and assessment of pertinent agronomic issues. J. Hazard. Mater. 3, (1-25), 2002.

5. MAZZEO R., NANNONI F., PROTANO G., MANTI A., SANTOLINI R. Integrated approach for the analysis of ecosystems at risk: a case study in a waste landfill. Environ Eng Manag J. 12, (S1), 165, 2013.

6. ÁLVAREZ E., FERNÁNDEZ MARCOS M.L., VAAMONDE C., FERNÁNDEZ-SANJURJO M.J. Heavy metals in the dump of an abandoned mine in Galicia (NW Spain) and in the spontaneously occurring vegetation. Sci. Total Environ. 313, (1-3), 185, 2003.
7. KOWALSKA J., STRYJEWSKA E, BYSTRZEJEWSKAPIOTROWSKA G., LEWANDOWSKI K., TOBIASZ M., PAŁDYNA J., GOLIMOWSKI J. Studies of Plants Useful in the Re-Cultivation of Heavy Metals-Contaminated Wasteland - a New Hyperaccumulator of Barium? Pol. J. Environ. Stud. 21, (2), 401, 2012.

8. VAVERKOVÁ M. D. ADAMCOVÁ D. Can vegetation indicate municipal solid waste landfill impact on the environment? Pol. J. Environ. Stud. 23, (2), 501, 2014.

9. ADAMCOVÁ D., VAVERKOVÁ M. D. Degradation of biodegradable/degradable plastics in municipal solid waste landfill. Pol. J. Environ. Stud. 23, (4), 1071, 2014.

10. VAVERKOVÁ M. D. ADAMCOVÁ D. Evaluation of landfill pollution with special emphasis on heavy metals. J. Ecol. Enginer. 2, (15), 1-, 2014.

11. CHAO W., XIAO-CHEN L., LI-MIN Z., PEI-FANG W., ZHI-YONG $\mathrm{G} . \mathrm{Pb}, \mathrm{Cu}, \mathrm{Zn}$ and $\mathrm{Ni}$ Concentrations in Vegetables in Relation to Their Extractable Fractions in Soils in Suburban Areas of Nanjing, China. Pol. J. Environ. Stud. 16, (2), 199, 2007.

12. KACHENKO A.G., SINGH B. Heavy Metals Contamination in Vegetables Grown in Urban and Metal Smelter Contaminated Sites in Australia. Water Air Soil Poll. 169, 101, 2006.

13. MALAYERI B.E., CHEHREGANI A., YOUSEFI N., LORESTANI B. Identification of the hyper accumulator plants in copper and iron mine in Iran. Pakistan J Biol Sci. 11, (3), 490, 2008.

14. KURTEVA M.K. Comparative study on Plantago major and P. lanceolata (Plantaginaceae) as bioindicators of the pollution in the region of the Asarel Copper Dressing Works. Phytologia Balcanica 15, (2), 261, 2009.

15. PORĘBSKA G., OSTROWSKA A. Heavy Metal Accumulation in Wild Plants: Implications for Phytoremediation. Pol. J. Environ. Stud. 8, (6), 433, 1999.

16. RASKIN I., SMITH R.D., SALT D.E. Phytoremediation of metals: using plants to remove pollutants from the environment. Curr. Opin. Biotech. 8, (2), 221, 1997.

17. EBBS S.D., KOCHIAN L.V. Phytoextraction of zinc by oat (Avena sativa), barley (Hordeum vulgare), and Indian Mustard (Brassica juncea). Environ. Sci. Technol. 32, (6), 802, 1998.

18. BROWN S.L., CHANEY R.L., ANGLE J.S., BAKER A.J.M. Phytoremediation potential of Thlaspi caerulescens and Bladder Campion for zinc- and cadmium-contaminated soil. J. Environ. Qual. 23, 1151, 1994.

19. BROWN S.L., CHANEY R.L., ANGLE J.S., BAKER A.J.M. Zinc and cadmium uptake by hyperaccumulator Thlaspi caerulescens grown in nutrient solution. Soil Sci. Soc. Am. J. 59, 125, 1995.

20. TOLRA R.P., POSCHENRIEDER CH., BARCELO J. Zinc hyperaccumulation in Thlaspi caerulescens. I. Influence on growth and mineral nutrition. J. Plant Nutr. 19, (12), 1531, 1996.

21. JASION M., SAMECKA-CYMERMAN A., KOLON K., KEMPERS A.J. Tanacetum vulgare as a Bioindicator of Trace-Metal Contamination: A Study of a Naturally Colonized Open-Pit Lignite Mine. Arch. Environ. Con. Tox. 65, 442, 2013.

22. GUBKA D., WOLSKI K. Use of Turfgrasses in Landfill Leachate Treatment. Pol. J. Environ. Stud. 20, (5), 1161, 2011.

23. ŚLIWKA M., BARAN A., WIECZOREK J. Evaluation of Toxic Metal Bioaccumulation in a Reservoir of Flotation Tailings. Pol. J. Environ. Stud. 22, (3), 909, 2013.

24. ČSN EN ISO 11885 Water quality - Determination of selected elements by inductively coupled plasma optical emission spectrometry (ICP-OES). 
